\title{
Teacher Deployment Policy towards Effective School Management
}

\author{
Nurkolis \\ Program Studi Manajemen Pendidikan, \\ Universitas PGRI Semarang \\ Jawa Tengah, Indonesia \\ Email: nurkolis@upgris.ac.id
}

\begin{abstract}
The focus of this research was the process of policy-making of teacher deployment. The policy analysis refers to Anderson and Dunn i.e the problem formulation, policy formulation, policy determination, policy implementation, and policy evaluation. It is a policy research with case study in Semarang District. Data source from interviews with informants and policy documents. The problem formulation was the shortage of civil servant teachers and the large number of small school. Policy formulation was recruitment civil servant, utilization of private teachers, multigrade teaching, regrouping, and mobile teacher. Policy determination was schools regrouping. The determination of policy was Regulation of Semarang Regent No. 28/. Implementation of the policy created through two decisions of the Semarang Regent i.e. No. 900/0413/2014 and No. $900 / 0453 / 2015$. Because this policy was just starting to be implemented so that it has not found the existence of the policy evaluation. Setting up policy of teacher deployment in Semarang District was an attempt to bring about an effective school management.
\end{abstract}

Keywords--education policy, teacher deployment, district regulation, school regrouping, multigrade teaching, and mobile teacher.

\section{INTRODUCTION}

Policy analysis is the activity of creating the knowledge of and in the policy-making process. In creating knowledge of policy-making process analysis investigates the causes, consequences, and performance of public policies and programs [1]. Policy analysis in this study was education policy as a public policy in the area of education. Therefore it needs to be explained about the policy, public policy, and education policy.

Harman said that the policy is an implicit or explicit specification of courses of purposive action in dealing with a recognized problem and directed towards the accomplishment of some intended set of goals [2]. The policy is based on problems that have emerged, and problems that can be identified from the issues in the community [3].

Kroll said that public policy is considered as the structure and confluence of values and behavior involving governmental prescription [4]. Therefore in public policies require the function of institutional, legal, and structural and process behavior against any problems that arise.

Public policy has some characteristics were: basically related to public affairs; high of consequences, complex, dominated by uncertainty, the existence of disagreement related goals want to achieve [4]. According to Bridgman and Davis that public policy has five characteristics: has a goal to be achieved, involving decisions with consequences, a structured according to certain rules, in fact is political, and it was dynamic [5].

Education policy is the overall process of the formulating results and measures to achieve the goal of education in a society at a particular period of time [6]. Furthermore explained that education policy should be based on some aspect of: based on the needs of the students, linked to the vision and goals of education, based on efficiency, have clear goals in order to bring forth the right policies, and the formation of democratic society. Education policy is not made on the basis of power, interests and bureaucrats, and formulated rational.

According to Anderson [5] public policy process consists of five stages: formulation of the problem; policy formulation which contains the formulation of alternatives to solve the problem; the determination of what policies was the contents of the policy, who implement policy, how to implement the policy; policy implementation; and the evaluation of policy.

Meanwhile, Dunn [1] explained that the process of policy making was almost similar to Anderson that consists of 5 stages, namely the determination of the agenda is similar the determination of issues, policy formulation which contains an alternative policy, adoption of a policy was the determination of the contents of the selected alternative, the implementation of policies by determining the financial support and other resources, as well as policy assessment to find out whether the policy in accordance with the rules and has achieved the desired goal.

The question was how was the process of policy making in Semarang District to deploy teacher in order to make effective school management? Education policy analysis in this article follows the process of policy making by Anderson and Dunn namely: problem formulation, policy 
formulation, policy determination, policy implementation, and policy evaluation.

\section{LITERATURE REVIEW}

Wahap stated that there was four policies in order to realized the organization of education quality, namely: a structural approach, procedural and managerial approach, behavioral approach, and political approach. Structural approach was top down and structurally designed, implemented, controlled, and evaluated. Procedural and managerial approach includes three steps namely design programs (details of the task, the formulation of objectives, performance measures, costs, and time), implement programs, and conduct monitoring and evaluation. Behavioral approaches assume that the implementation of the policy will run well when considering human behavior so that there was no refusal from the implementers and the community. The political approach in the education policy pay attention to politics or power factor and allows the use of force from the dominant group [7].

The process of policy formulation according to Harman including four stages namely: identification of issues and problems, the formulation of problems and implementation strategies, formal authorization by implementing various programs, as well as termination of the changes because the problem was already solved [2].

The analysis of education policy in order to improve the quality of education was very rare performed in Indonesia [8]. Moreover, the existence of analysis of education policy in meso level was more rare. Whereas research policy was one of an important field of study in the social sciences, but in fact it was very rare [9]. One of the comprehensive analysis of education policy at the meso level was done in Jembrana-Bali consisted of policy formulation, policy implementation, policy performance, and policy process [6].

One of the conclusions from the results of research in the Government of Jambi Province stated that education policy made in the incidental nature and still haven't planned properly. This is caused by the construction of a database that has not been oriented on the development of quality education [10].

Analysis of the education policies was indispensable in Indonesia to improve the effectiveness of educational management. The effectiveness of teacher management was very necessary as expressed by the OECD/ADB [11]. Another statement that the recent decision to expand universal participation in education from 9 to 12 years will necessitate much greater effectiveness in deployment of teachers alongside a better alignment of the breadth of programmed offered. One of the problems facing the world of education in Indonesia is efficiency. So in education also need efficiency, including in the use of resources of the teacher. OECD/ADB further said, "Indonesia devotes $20 \%$ of government expenditure to education. Capitalizing this implies increasing investment efficiency. This will requires a more transparent and performance stronger management".
Less effective and efficient of teacher management happen in much country like Indonesia [15], Nepal [16], Africa [17], even in China [18]. Unfortunately research about teacher management often forgotten so rarely found the best practice on it.

\section{METHOD}

This article is based on research-policy with case study type associated with the process of education policies in Semarang District of Central Java Province. The research was carried out with meso-level analysis, namely medium policy or intermediate analysis which focused on relation between definition of problem, determining the agenda, the process of decision making, and implementation [3]. Policy analysis about teachers deployment created by the Regent of Semarang in Central Java Province within year 2014-2015 consists of: (a) rules of regent No. 28/2014 regarding technical guidelines for the regrouping of the elementary school in Semarang District, (b) regent decree No. 900/0413/2014 regarding the determination of the regrouping of the elementary school in Semarang District, and (c) the regent decree No. 900/0453/2015 about determination of merger/regroup in public elementary school in Semarang District. Data obtained from interviews with participants of the focus group discussion with policy makers policy documents in the form of a regulation or decision of the regents.

\section{RESULTS AND DISCUSSION}

\section{A. Problem Formulation}

The data used as the basis to find the problem in this research was the basic of education data (called Dapodik). Each school regularly filled these data. Any changes of data included the number of teachers, the number of students, the number of classes, condition of facilities and infrastructure, as well as a number of schools will be updated in online system. This data was also stored on the server of the ministry of education and culture nationwide and can be used by different interested parties.

School which will be analyzed were only public elementary school, because the private elementary school owned by the community so that the local government of District Semarang could not do the merger of private schools without any request from the community.

The number of public elementary schools were 495 schools scattered in 19 sub districts and be analyzed totally $(100 \%)$. The number of civil servant teachers was analyzed from 3,411 out of 4,791 total teacher $(87,7 \%)$. Means that $22.3 \%$ of the teachers were not analyzed because incomplete data. Public elementary school teachers were analyzed from a few things, namely adequacy of class teachers, adequacy of subjects teachers of physical education and health, and adequacy of subjects teacher of Islamic.

The need of the civil servant class teachers were 3,019 people while the civil servant class teacher available as 
much as 2,466 people, or shortage of 553 teacher. On the other hand there were 524 private teachers available. All sub districts experiencing a shortage of civil servants teachers. If the existence of private teachers taken into account there was only 10 sub district with enough teachers, but 9 sub district lack a civil servant teachers. The existence of private teachers was not completely reliable due to the uncertain of their status.

The needs of subject teachers for physical education and health were 440 teachers while 313 teachers available. Although there were 93 private teachers available, the shortage of subjects teacher still exist.

The needs for Islamic teacher were 377 teachers, but only 302 teachers available. The shortfall had been closed by a private teachers or school principal.

What about class size? Of total 495 schools there were 130 schools that the number of students for each class less/equal to 16 students $(24 \%)$ that spreads in all sub district. The majority of schools have a number of students per class between 17-32 students that was as much as 305 schools $(57 \%)$. But there are also a number of school that the number of student over 40 student each class that is as much as 24 of the school or $5 \%$.

As seen from the number of teacher and the number of student per class, indicates that the public elementary school in Semarang District was not managed efficiently and effectively. Therefore need to be supported by an effective school management.

The data above shown that there were two related problems with teacher in public elementary schools, namely: (a) a shortage of civil servant teacher, and (b) there were still many small schools. In accordance with the opinion of Davis that the policy will be made to address the issue of teacher deployment.

\section{B. Policy Formulation}

In order to overcome the above problem there were various policy alternatives presented and each accounted for the consequences. First, propose to the central government for the recruitment of prospective civil servants teachers in accordance with the shortage of the class teachers, subject teachers of sport and health education, as well as subject teachers of Islamic religious education in public elementary schools. The risk of this policy alternatives will be rejected by the central government, because Semarang District have been using $51 \%$ of its budget for indirect spending (the largest components of indirect spending was salaries). The central government has decided that if the district government expenditures exceeding $50 \%$ for expenditure for salary then it was not allowed to perform the addition of new civil servants candidates.

Second, the empowerment of private teacher by providing higher salaries and allowances in accordance with rule of governor regulation. Empowerment in this case does not mean elevating them to be civil servants, but rather became honorary teachers with salary in accordance with the regional minimum wage standards of Semarang District in 2016 amounting to Rp. 1,610,000. This was in accordance with the decision of the Governor of Central Java applied in 2016 [12]. These alternative consequences big enough because the local authorities must provide a budget of Rp. 10,683,960,000 for one year to hire 553 people became private teacher using scheme government employees with the work agreement in accordance with Act No. 5 by 2014 about Civil State Apparatus [13]. Another consequence was the existence of demands from private teacher to become a civil servant after they become teachers of local government contracts. Note that since 2014 when President Joko Widodo has declared a moratorium of civil servants acceptance.

Third, application of multigrade teaching to address the shortage of teacher. If policy makers choose this alternative, the consequences should conduct training to teachers so that multigrade teaching run good without harming students. In fact not many experts able to train multigrade teaching with successful result.

Fourth, the merger of the schools (regrouping) i.e. combining small schools nearby or merges schools located in one place. The risk of this regrouping was the refusal from the citizens of the community, teachers, and principals who will miss school or school locations are farer from their residence.

Fifth, applying mobile teacher that the teachers who teach at more than one school. An alternative to this policy was also at risk since the majority of teachers teaching in their schools with the allocation of teaching hour in accordance with the load of a minimum of 24 hours per week i.e. as mandated rules upon No. 74 in 2008 about teacher [14]. If this policy was implemented then it can happen the manipulation of teaching hours, manipulation of classes, or scrambling hours of teaching among teachers.

\section{Policy Determination}

Among various alternative policies mention above, the district of education and the team choose regrouping of the school because it has the lowest risk. Fears of rejection from teachers, principals, and society can be overcome by involving them on the discussions from the beginning of finding the problems faced by the district government. With these problems, then the parties understand the issues and then support the plan of school merger. Finally the team formulated a policy and proposes to the Regent of Semarang to create written policies.

Determination of policy began with the issued of the regulations of the regents No. 28/2014 regarding technical guidelines for the regrouping of the elementary school in Semarang District. The scope of the merger of schools consisted of two, namely the school campus and small schools.

The criteria of technical education in the school campus was a merger of two or more public elementary school located in a school environment, the distance between the school no more than 200 meters, the number of groups of study not exceed the number of class, and there was not 
conflict with the spatial plan of the region.

The technical criteria of education of merging small school was number of student no more than 80 students, the distance between the school no more than 1,000 meters, there were no barriers to access, in one village there were more than 1 public elementary schools, there was not in the area of the border district, and did not conflict with the spatial plan of the region.

In addition to the technical criteria of the education there were still the technical criteria of building, technical reliability criteria of the building, and the stages of merging schools starting from the preparations of data collection, verify data, determination of core schools, school assignment that will be merged into the core school, followed by the stage of proposal, discussion, and determination, as well as the implementation of the merger of the school.

This policy also specified that the Regent of Semarang, headed the team that made by the head of Department of Education and Culture, assisted by a secretary that was secretary of the Department of Education and Culture, as well as eight members of the team comes from various work units in District Government of Semarang.

At the level of head of sub district, was also formed a team, chaired by the head of the unit for the education of sub district. It was assisted by a secretary and composed of six people from the different working units in the neighborhood of sub districts.

\section{Policy Implementation}

Policy implementation of teacher deployment done by the Regent of Semarang by issuing the following two decisions.

First, the Regent of Semarang Decision No. 900/0413/2014 regarding the determination of the regrouping of the public elementary school in Semarang decided there were 25 schools that merged into 12 new schools by using one of the school names or using the new name.

Second, the decision of the Regent of Semarang No. 900/0453/2015 about determination of merger/regroup of public elementary school in Semarang decided there were 24 schools that merged into 12 new schools.

The first and second decision of regrouping was explained that the merger of the school carried out with taking into account the efficiency of the operational costs of education. Asserted that the merger of these schools was an attempt to overcome the shortage of civil servant teachers, improving the quality of education, and to improve the effective management of education. Expressly affirmed that all costs resulting from the decision was charged to the income and expenditure of district budget.

Based on the two decisions then starting from the new school year 2015/2016 the implementation was effective run that started to the transfer of students, facilities and infrastructure, and teachers also.
Now the students and teachers from two or three schools regrouped have already merged into one school. Similarly the school facilities and infrastructure that needed were combined into one. Meanwhile, infrastructure and facilities that are no longer needed to be returned to the local government assets.

\section{E. Policy Evaluation}

This policy was just implemented earlier in July 2015 a new academic year. Means that it was at the beginning of the implementation. Therefore the evaluation policy has not been made and has not been reported in this article.

\section{CONCLUSION}

The process of policy making to deploy teacher in District Semarang was done systematically i.e. problem formulation, policy formulation, policy determination, policy implementation, and policy evaluation.

The policy based on the problem arises. The problems were less efficient and effective of education resulting from the large number of small schools and a shortage of teachers. Problems can be found after analyzing data on education in a comprehensive manner from the basic data of education. The respective schools updated the data in each single semester. So that changes that occur in schools such number of teacher, number of students, number of class, and the condition of school facilities and infrastructure reported thoroughly.

The regent decision and regulation of Semarang District as a form of public policy in education was a function of structural, institutional, legal, and a process to resolve problems that raised in education.

Education policy made by the regent of Semarang already based on some aspect of: needs of the students, linked to the vision and goals of education, based on efficiency, have a clear goal, and finally expected the formation of democratic society.

This education policy process use blend of managerialprocedural approach and behavioral approach. This can be evidenced from steps of policy making which starts from program design including the formulation of goals, implementing the program, and conduct monitoring and evaluation. Before being implemented, a public consultations done to obtain the support of the parties affected by the policy. This applied behavioral approved.

This education policy was good example for enhancing the quality of education. Because educational policy was made not based of power, interests and bureaucrats, and done rational. If the policies made by the leaders of education were done in this way, then the attempt to realize effective of education management was inevitability.

Up to recently, there was no monitoring and evaluation to this policy. This was because the implementation of the policy has just started. Therefore this research needs to be followed up with a policy impact research. 


\section{ACKNOWLEDGMENT}

The research was funded by the postgraduate research grants of the Ministry of Research and Technology of Higher Education in 2016. This research was the second year of research. The first year research (2015) focuses on the search for a model of effective school management on the micro level i.e. education unit. The second year focus was the analysis of the policy decisions made by the head of the region to improve the quality of education.

The process of policy-making was facilitated by the United State Agency for International Development through USAID PRIORITAS program in Central Java Province. One of the activities in this program was mentoring district to make education policy on teacher deployment in Semarang District.

\section{REFERENCES}

[1] Dunn, William N. Public Policy Analysis: An Introduction. New Jersey: Pearson Education. 1994, p.1. and pp.15-16.

[2] Hough, J.R (Editor). Educational Policy: An International Survey. Sydney: Croom Helm. 1984, pp.13-17.

[3] Parsons, W. Public Policy: Pengantar Teori dan Praktik Analisis Kebijakan (Terjemahan Santoso, TB). Jakarta: Kencana Prenadamedia. 2014, pp. 87-89.

[4] Mann, D. Policy Decision-Making in Education: An Introduction to Calculation and Control. New York: Teacher College Press. 1975, pp.10-11.

[5] Nawani, I. Public Policy: Analisis, Strategi Advokasi, dan Praktek. Surabaya: Putra Media Nusantara. 2009, pp.8-9 and pp. 15-16.

[6] Tilaar, H.A.R and Nugroho, R. Kebijakan Pendidikan: Pengantar Untuk Memahami Kebijakan Pendidikan Dan Kebijakan Pendidikan Sebagai Kebijakan Publik. Yogyakarta: Pustaka Pelajar. 2009, pp.370-430 and pp.140-154.

[7] Rohman, A dan Wiyono, T. Education Policy in Decentralization Era. Yogyakarta: Pustaka Pelajar. 2010, pp.7-13.

[8] Suryadi, A dan Budimansyah D. Paradigma Pembangungan Pendidikan Nasional: Konpep, Teori, dan Aplikasi dalam Analisis Kebijakan Publik. Bandung: Widya Aksara Press. 2009, p.144.

[9] Nugroho, Riant. Metode Penelitian Kebijakan. Yogyakarta: Pustaka Pelajar. 2013, p.43.

[10] Sutrisno dan Rusli, M. Analisis Kebijakan Peningkatan Mutu Pendidikan Dasar dan Menengah di Provinsi Jambi. Jurnal Pendidikan Inovatif Volume 3 Nomor 1, September 2007, p. 31.

[11] OECD/Asian Development Bank. Education in Indonesia: Rising to the Challenge. Paris: OECD Publishing. http://idx.doi.org/10.178719764230750-en. 2015, p.21.

[12] Keputusan Gubernur Jawa Tengah Nomor 560/66/2015 Tentang Upah Minimum Pada 35 (Tiga Puluh Lima) Kabupaten/Kota di Provinsi Jawa Tengah Tahun 2016.

[13] Undang-Undanga Republik Indonesia Nomor 5 Tahun 2014 tentang Aparatur Sipil Negara.

[14] Peraturan Pemerintah Republik Indonesia Nomor 74 tahun 2008 tentang Guru.

[15] Sulistyono, T. Model Koordinasi Pengelolaan Guru Pns Di Dinas Pendidikan Kota Yogyakarta Pada Era Otonomi Daerah. Cakrawala Pendidikan, Februari 2014, Th. XXXIII, No. 1, Pp.1-12

[16] Paneru, D.R. Teacher Management And Development In Higher Secondary Education: A Case Of Higher Secondary Education Board Of Nepal. Journal Of Management \& Development Economics, April 2015 Vol. 4 Issue No. 1 ISSN 2392-4551, pp. 19-30.

[17] Mulkeen, A. 2010. Teachers in Anglophone Africa: Issues in Teacher Suply, Training, and Management. Washington D.C: The World Bank.
[18] Huang, E; Benson, J; and Zhu, Y. 2016. Teacher Management in China: The Transformation of Educational System. New York: Routledge. 